Tropical Journal of Pharmaceutical Research June 2019; 18 (6): 1161-1166

ISSN: $1596-5996$ (print); 1596-9827 (electronic)

(C) Pharmacotherapy Group, Faculty of Pharmacy, University of Benin, Benin City, 300001 Nigeria.

\title{
Floroindole confers protection against cecal ligation and puncture-induced sepsis via inhibition of NF-kB p65 phosphorylation
}

\author{
Zhiwen Zhou', Xiang Ren ${ }^{1}$, Aiping Li ${ }^{1}$, Wensheng Zhou', Li Huang ${ }^{2 *}$ \\ ${ }^{1}$ Department of Neurology. Hunan Provincial People's Hospital, The First Affiliated Hospital of Hunan Normal University, \\ Changsha, Hunan 410016, ${ }^{2}$ Department of Critical Care Medicine, Xiangya Hospital, Central South University, Changsha, \\ Hunan 410008, China
}

*For correspondence: Email: lesueer@yahoo.com; Tel: 0086-0731-89753999

Sent for review: 28 January 2019

Revised accepted: 27 May 2019

\begin{abstract}
Purpose: To investigate the protective effect of floroindole against cecal ligation and puncture (CLP)induced sepsis, as well as the underlying mechanism of action.

Methods: Thirty-five 10-week-old male Wistar rats weighing $190-210 \mathrm{~g}$ (mean: $200.00 \pm 10.10 \mathrm{~g}$ ) were used for this study. The rats were randomly assigned to seven groups of five rats each, viz, normal control group, and six CLP groups. The CLP groups were those subjected to cecal ligation and puncture $(C L P)$. The first 5 CLP groups received 2, 4, 6, 8 or $10 \mathrm{mg} / \mathrm{kg}$ floroindole, respectively, $1 \mathrm{~h}$ after CLP, via intraperitoneal route (i.p.) while the 6th CLP group served as untreated control. Western blotting, enzyme-linked immunosorbent assay (ELISA) and real-time quantitative polymerase chain reaction (qRT-PCR) were used for the assessment of the expression levels of tumor necrosis factor- $\alpha$ (TNF- $\alpha)$, interleukn-6 (IL-6), nucleotide-binding oligomerization domain 2 (NOD2) and p-NF-KB p65.

Results: Cecal ligation and puncture (CLP) significantly and time-dependently upregulated the expressions of TNF- $\alpha, I L-6$ and NOD2 in intestinal tissues of rats $(p<0.05)$. However, treatment with floroindole significantly, and dose-dependently down-regulated CLP-induced expressions of these proteins $(p<0.05)$. Treatment of rats with floroindole also significantly and dose-dependently inhibited CLP-induced phosphorylation of NF-KB p65 in rat ileum $(p<0.05)$.

Conclusion: The results obtained in this study demonstrate that floroindole confers some degree of protection against CLP-induced sepsis via inhibition of NF-KB p65 phosphorylation.
\end{abstract}

Keywords: Sepsis, Cecal ligation, Cytokines, Expression, Phosphorylation

This is an Open Access article that uses a fund-ing model which does not charge readers or their institutions for access and distributed under the terms of the Creative Commons Attribution License (http://creativecommons.org/licenses/by/4.0) and the Budapest Open Access Initiative (http://www.budapestopenaccessinitiative.org/read), which permit unrestricted use, distribution, and reproduction in any medium, provided the original work is properly credited.

Tropical Journal of Pharmaceutical Research is indexed by Science Citation Index (SciSearch), Scopus, International Pharmaceutical Abstract, Chemical Abstracts, Embase, Index Copernicus, EBSCO, African Index Medicus, JournalSeek, Journal Citation Reports/Science Edition, Directory of Open Access Journals (DOAJ), African Journal Online, Bioline International, Open-J-Gate and Pharmacy Abstracts

\section{INTRODUCTION}

Sepsis is a complicated clinical syndrome caused by inflammatory reactions to microbial invasion [1]. This condition is characterized by high mortality [1]. Sepsis alone accounted for about $9 \%$ of total deaths in the United States in $2000[2,3]$. Although several studies have attempted to unravel the mechanism underlying the pathogenesis of sepsis, no effective treatment has been developed till date. Thus, the development of new drugs that can effectively 
treat sepsis has become necessary. The upregulation of cytokine expression enhances membrane permeability, alters cellular metabolic pathways and induces coagulopathy [4]. These changes are associated with the development of multiple organ failure syndrome [4]. In humans, pro-inflammatory cytokines, i.e., TNF- $\alpha$, IL-6 and interleukin-8 (IL-8) are released during severe pathogen infections $[5,6]$. In patients with sepsis, the network of cytokines is regulated through the release of TNF- $\alpha$ and IL-6 $[5,6]$.

Indole, also known as benzopyrrole, is a bicyclic heteroaromatic compound consisting of sixmembered benzene ring fused with five membered nitrogen-bearing pyrrole [7]. It is a structural component of several natural products such as vinca alkaloids which are metabolites isolated from fungal materials [7]. Compounds synthesized from indole have been shown to possess varied pharmacological properties, including anti-inflammatory effect. The compound [2- (3-oxo-3, 4-dihydro-2H-benzo[1,4]oxazin-6carbonyl)- $1 \mathrm{H}$-indol-3yl]acetic acid is an indole derivative which exerts anti-inflammatory effect through the inhibition of cyclooxygenase-2 (COX2) $[8,9]$. Several other derivatives of indole such as 2-(p-chlorophenyl)-1-[4-(2-(p-chorophenyl)-4oxo-thiazolidin-3-yl]-5-mercapto[1,2,4,]-trizole-3yl-methyl]-3[4,6-dibromo-2-

carboxyphenyliminomethyl]-5-methoxyindole and 2-(1H-indol-3-yl)-6-methoxy-4-pentylpyridine-3,5dicarbonitrile, have also been reported to possess significant anti-inflammatory properties $[10,11]$. The present study investigated the protective effect of floroindole against CLPinduced sepsis, and the underlying mechanism.

\section{EXPERIMENTAL}

\section{Materials}

Wistar rats were purchased from Shanghai SLAC Laboratory Animal Co., Ltd. (China). Phosphate buffered saline (PBS) was obtained from BioDiagnostics Company (Egypt). Rabbit polyclonal anti-p-NF-kB p65 was a product of Cell Signalling Technology (USA); mouse monoclonal anti-IL-6 was purchased from Sigma-Aldrich (USA), and horseradish peroxidase-conjugated secondary antibody was obtained from Santa Cruz Biotechnology, Inc. (USA). Phenylmethanesulfonyl fluoride was a product of Sigma (USA), while TNF- $\alpha$ and NOD2 ELISA kits were obtained from Diaclone (France). Interleukin-6 ELISA kit was purchased from BioSource (Belgium), and Trizol reagent was obtained from Invitrogen Co., Ltd. (USA). RotorGene 6000 RT-PCR machine was a product of Corbett Research (Australia), while SYBR
Premix Ex Taq was obtained from Thermo Fisher Scientific (USA).

\section{Experimental rats}

Thirty-five 10-week-old male Wistar rats weighing $190-210 \mathrm{~g}$ (mean weight $=200.00 \pm 10.10 \mathrm{~g}$ ) were used for this study. The rats were housed in plastic cages under standard laboratory conditions: $12 \mathrm{~h}$ light/dark cycles, $25{ }^{\circ} \mathrm{C}$ and $50-$ $60 \%$ humidity. They had free access to feed and clean drinking water. The study protocol was approved by the Ethics Committee for Care and Use of Laboratory Animal, Shanghai University (approval no. SUWR/16/102). The Guidelines of "Principles of Laboratory Animal Care" (revised $\mathrm{NIH}$ publication 85-23 were followed to provide humane care to all the rats [12].

\section{Treatment regimen and grouping}

The rats were randomly assigned to seven groups of five rats each, viz, normal control group and six treatment groups. The treatment groups were subjected to CLP. Five of the treatment groups received 2, 4, 6, 8 or $10 \mathrm{mg} / \mathrm{kg}$ floroindole $1 \mathrm{~h}$ after CLP via intraperitoneal route (i.p.). The sixth CLP group served as untreated control. The normal and untreated controls received equivalent volumes of physiological saline in place of floroindole. Two rats from each group were sacrificed at different time points: 2 , 4, 6, 8 and $10 \mathrm{~h}$ of CLP after isoflurane anesthesia, and the ileal tissues excised and kept at $-78^{\circ} \mathrm{C}$ prior to use.

\section{Establishment of sepsis model}

The rat model of sepsis was established using CLP procedure. The rats were subjected to isoflurane anaesthesia and a small incision (2 $\mathrm{cm}$ ) was carefully made on the ventral side along the ventral abdominal midline. The cecum of the rat was exposed and then immediately ligated next to ileocecal valve using 3-0 silk suture to avoid obstruction in the intestine. An 18-gauge needle was used for making puncture in the cecum between ligation and the cecum. The punctured cecum was put back into the peritoneal cavity and the incision was stitched using thin 6-0 silk suture under sterile conditions. Rats in the sham group were subjected to same procedure, except CLP.

\section{Western blotting}

The ileum of each rat treated with floroindole was excised under isoflurane anesthesia and washed twice with phosphate-buffered saline (PBS). A tissue homogenate was prepared on ice in 
HEPES buffer (10 mM, pH 8.0) which comprised potassium chloride $(10 \mathrm{mM})$, magnesium chloride (2 mM), EDTA (0.1 mM), dithiothreitol (1.0 mM) and phenylmethanesulfonyl fluoride $\left(\mathrm{PhCH}_{2} \mathrm{SO}_{2} \mathrm{~F}, 0.5 \mathrm{mM}\right)$. The tissue homogenate was centrifuged at $4,000 \mathrm{rpm}$ for $25 \mathrm{~min}$ at $4{ }^{\circ} \mathrm{C}$, and the protein concentration in the supernatant was determined using bicinchoninic acid (BCA) assay kit. Protein separation was achieved on 12 $\%$ sodium dodecyl sulphate (SDS)polyacrylamide gel electrophoresis (PAGE) and transferred to a fixed polyvinylidene fluoride membrane at $110 \mathrm{~V}$ and $90^{\circ} \mathrm{C}$ for $120 \mathrm{~min}$. Non-fat milk powder (3\%) in Tris-buffered saline containing $0.2 \%$ Tween-20 (TBS-T) was added with gentle shaking at $37^{\circ} \mathrm{C}$ and incubated to block non-specific binding of the blot.

The blot was incubated overnight (at $4{ }^{\circ} \mathrm{C}$ ) with primary antibodies of rabbit polyclonal anti-p-NFKB p65, mouse polyclonal anti-TNF- $\alpha$, mouse monoclonal anti-IL-6, NOD2 and $\beta$-actin at a dilution of 1 to 1000 . Then, the membrane was washed thrice with TBS-T and further incubated with horseradish peroxidase-conjugated goat anti-rabbit lgG secondary antibody for $1 \mathrm{~h}$ at room temperature. The blot was developed using an Xray film. Grayscale analysis of the bands was performed using Enhanced chemiluminescence (ECL). The respective protein expression levels were normalized to that of $\beta$-actin which served as control.

\section{Enzyme-linked immunosorbent assay (ELISA)}

Excised rat ileum was washed twice in PBS, blotted dry in filter paper and weighed. The ileal tissues were homogenized on ice in HEPES buffer $(10 \mathrm{mM}, \mathrm{pH} 8.0)$ which consisted of potassium chloride $(10 \mathrm{mM})$, magnesium chloride (2 mM), EDTA (0.1 mM), dithiothreitol $(1.0 \mathrm{mM})$ and $\mathrm{PhCH}_{2} \mathrm{SO}_{2} \mathrm{~F}$ (0.5 mM). The tissue homogenates were centrifuged at $4,000 \mathrm{rpm}$ for $25 \mathrm{~min}$ at $4{ }^{\circ} \mathrm{C}$ to obtain supernatant, which was refrigerated at $-78{ }^{\circ} \mathrm{C}$ till required. The levels of TNF- $\alpha$ and IL-6 were determined in the supernatant using their respective ELISA kits.

\section{Quantitative real-time polymerase chain reaction (qRT-PCR)}

Total RNA from homogenized ileal tissues of rats was isolated using Trizol reagent. The synthesis of cDNA from RNA was performed using Reverse Transcriptase M-MLV (RNase H) kit. The reaction conditions were: 1 cycle of $5 \mathrm{~min}$ at $93{ }^{\circ} \mathrm{C}, 10$ cycles of $30 \mathrm{~s}$ at $92{ }^{\circ} \mathrm{C}, 30 \mathrm{~s}$ at $67^{\circ} \mathrm{C}$, and $30 \mathrm{~s}$ at $70{ }^{\circ} \mathrm{C}$, followed by 27 cycles of $30 \mathrm{~s}$ at $92^{\circ} \mathrm{C}, 30 \mathrm{~s}$ at $54^{\circ} \mathrm{C}$, and $30 \mathrm{~s}$ at $70{ }^{\circ} \mathrm{C}, 10 \mathrm{~min}$ at $70{ }^{\circ} \mathrm{C}$ for 1 cycle. Electrophoresis was performed on $2 \%$ agarose gel for separation of PCR products and normalization of the mRNA expression level was done with GAPDH. RotorGene 6000 RT-PCR machine connected to the SYBR Premix Ex Taq was used for running the qRT-PCR. Analysis of the data was performed in accordance with the ${ }^{2-} \Delta \Delta \mathrm{Ct}$ method. The primer sequences used are shown in Table 1.

Table 1: Primer sequences used for NOD2 and $\beta$ actin qRT-PCR

\begin{tabular}{llll}
\hline Variable & Forward & \multicolumn{1}{l}{ Backward } \\
\hline NOD2 & ATC CCT & CGG & GCT TCC TGA ATA \\
& TTA CTA TGT TG & CTC CTC CT \\
$\beta$-Actin & CCC ATC & TAT & TTA ATG TCA CGC \\
& GAG GGT & TAC & ACG ATT TC \\
& GC & & \\
\hline
\end{tabular}

\section{Statistical analysis}

Data are expressed as mean \pm SEM. Statistical analysis was performed using SPSS (version 15.0). Groups were compared using Student $t$ test. Values of $p<0.05$ were considered statistically significant.

\section{RESULTS}

\section{CLP-induced expressions of TNF- $\alpha$ and IL-6}

As shown in Figure 1, CLP significantly and timedependently upregulated the expressions of TNF- $\alpha$ and IL- 6 in intestinal tissues of rats $(p<$ $0.05)$.

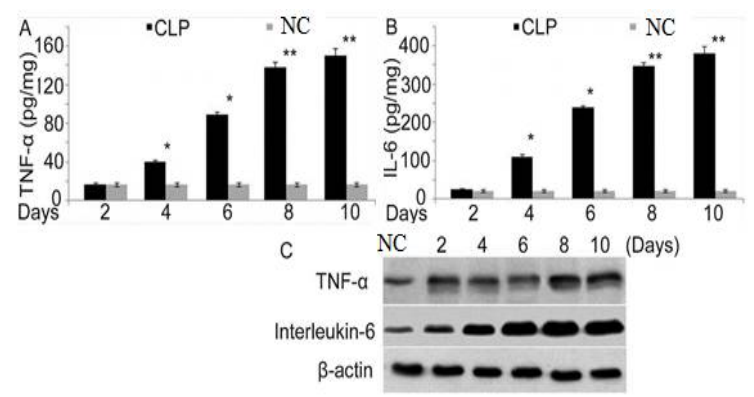

Figure 1: Effect of CLP on the expressions of TNF- $\alpha$ and IL-6. (A) Expressions of TNF- $\alpha$ and IL-6 as determined using ELISA; and (B) Expressions of TNF$\alpha$ and IL-6 measured using Western blotting; $p<0.05$ $\&{ }^{* \star} p<0.01$, when compared with normal control group

\section{Effect of floroindole on CLP-induced expressions of TNF- $\alpha$ and IL- 6}

Floroindole significantly, and dose-dependently down-regulated CLP-induced expressions of TNF- $\alpha$ and IL-6 ( $p<0.05$; Figure 2). 


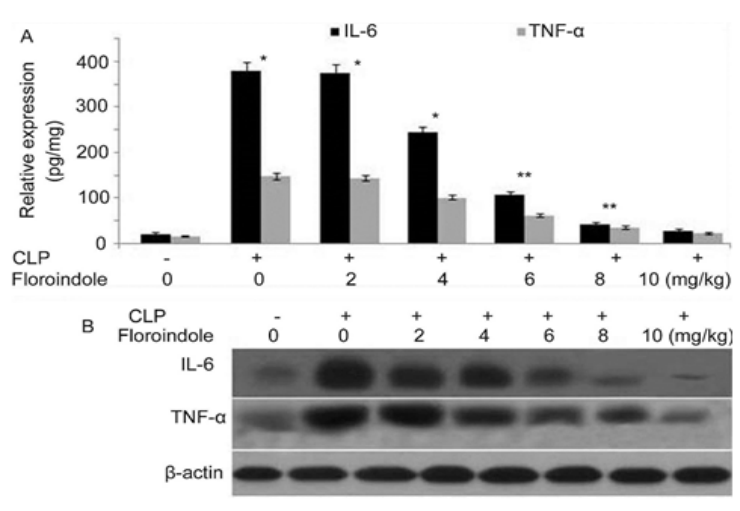

Figure 2: Effect of floroindole on the expressions of CLP-induced TNF- $\alpha$ and IL-6. (A) Expressions of TNF$\alpha$ and IL- 6 as measured using ELISA; and (B): Expressions of TNF- $\alpha$ and IL- 6 as measured using Western blotting; $p<0.05$ and ${ }^{*} p<0.01$, when compared with normal control group

CLP-induced expression of NOD2 in rat intestinal tissues

As shown in Figure 3, CLP significantly and timedependently increased the expression of NOD2 mRNA in intestinal tissues of rats $(p<0.05)$.

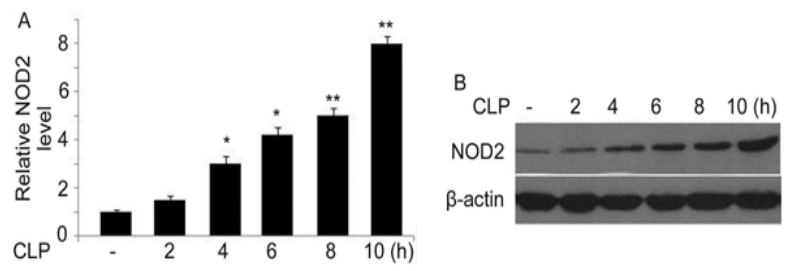

Figure 3: Effect of CLP on expression of NOD2 mRNA. (A) Expression of NOD2 as measured using ELISA; and (B) Expression of NOD2 measured using Western blotting; $p<0.05$ and ${ }^{* *} p<0.01$, when compared with normal control group

\section{Effect of floroindole on CLP-induced NOD2 expression}

Treatment of rats with floroindole significantly and dose-dependently inhibited CLP-induced expression of NOD2 in rat intestine $(p<0.05$; Figure 4).

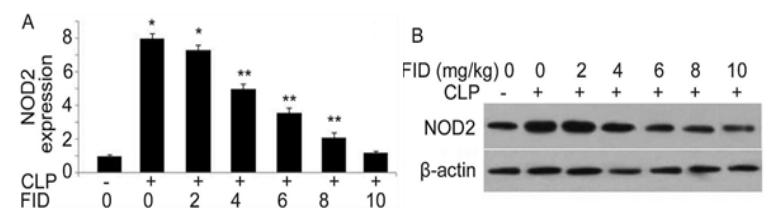

Figure 4: Effect of floroindole on CLP-induced overexpression of NOD2. (A) Expression of NOD2 mRNA, as determined using ELISA; and (B) expression of NOD2 mRNA, determined using Western blotting. $p<0.05 \& " p<0.01$, when compared with normal control group

\section{CLP-induced phosphorylation of NF-kB p65}

The results of Western blotting and qRT-PCR showed that CLP significantly and timedependently promoted NF-KB p65 phosphorylation in rat ileum relative to normal control group $(p<0.05$; Figure 5).

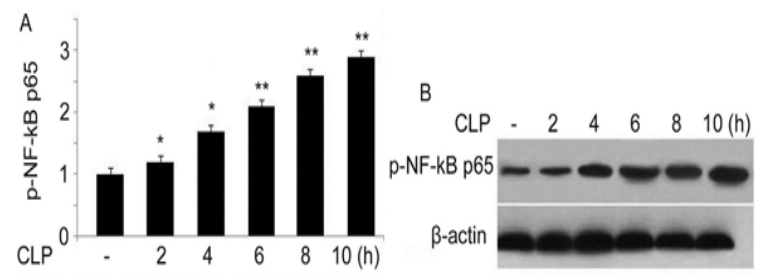

Figure 5: Effect of CLP on phosphorylation of NF-KB p65. (A) Expression of p-NF-kB p65, as measured using qRT-PCR; and (B) Expression of p-NF-kB p65, as measured using Western blotting; $p<0.05 \&$ \& $p<$ 0.01 , when compared with normal control group

\section{Effect of floroindole on CLP-induced phosphorylation of NF-kB p65}

Treatment of the rats with floroindole significantly and dose-dependently inhibited CLP-induced NF-kB p65 phosphorylation in rat ileum $(p<$ 0.05). These results are shown in Figure 6.

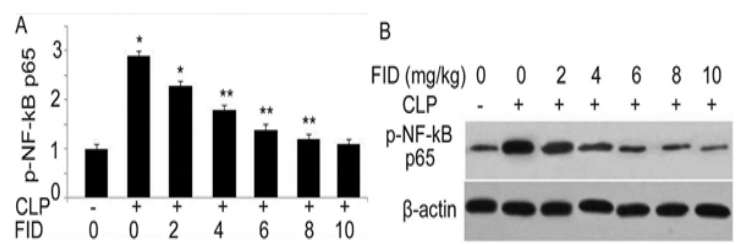

Figure 6: Effect of floroindole on CLP-induced NF-kB p65 phosphorylation. (A) Expression of p-NF-kB p65 as determined using qRT-PCR; and (B) Expression of $\mathrm{p}-\mathrm{NF}-\mathrm{kB}$ p65 as determined using Western blotting; $\mathrm{p}$ $<0.05 \&{ }^{\star *} p<0.01$, when compared with normal control group

\section{DISCUSSION}

Sepsis is a potentially life-threatening condition caused by physiological response to infection. The human body normally releases antibodies and complement proteins into the systemic circulation to fight infections. Sepsis occurs when these antibodies and complement proteins are overwhelmed, thereby triggering changes that damage multiple organs [1]. The present study investigated the protective effect of floroindole against CLP-induced sepsis, and the underlying mechanism. The results showed that floroindole significantly and dose-dependently suppressed CLP-induced expressions of TNF- $\alpha$, IL- 6 and NOD2, and NF-KB p65 phosphorylation in rat intestine. These results suggest that floroindole 
may inhibit inflammatory reactions during sepsis. Sepsis is caused by the invasion of infectious particles leading to inflammatory reactions and ultimately cell injury $[1,13]$. In some cases, the inflammatory reactions lead to multi-organ failure $[1,13]$. At the initial stage, sepsis induces release of pro-inflammatory cytokines from intestinal tissues, which not only damage the intestine itself, but also affect the functioning of distant organs [14]. There is a strong association between the expression of pro-inflammatory cytokines and sepsis.

Nucleotide-binding oligomerization domain 2 (NOD2) exists as a cytosolic receptor for providing immunity to cells against various infectious agents [15]. It recognises the peptidoglycan portion of bacterial cell wall and then generates appropriate signals for the activation of receptor-interacting protein 2 (RIP2) $[16,17]$. The activated RIP2 in turn induces proinflammatory reactions and anti-infective responses leading to onset of infection inhibitory loop [16-18].

The peptidoglycan recognition capability of NOD2 is inhibited by polymorphism in the gene which encodes NOD2 protein [19]. The expression of NOD2 plays a key role in the phosphorylation of NF-KB [19]. In the present study, there were marked increases in the expressions of NOD2 mRNA and protein in rat intestinal tissues subjected to CLP. However, these increases were significantly and dosedependently inhibited by floroindole treatment.

Nuclear factor kappa-light-chain-enhancer of activated $B$ cells (NF-KB) regulates genes which encode inflammatory cytokines such as TNF- $\alpha$ and IL-6 $[1,20]$. The phosphorylation of NF-KB increases the incidence of mortality in patients with sepsis [21]. In animal models of sepsis, inhibition of NF-KB phosphorylation has been found to elicit some therapeutic effects $[22,23]$.

\section{CONCLUSION}

The results obtained in this study indicate that floroindole confers some degree of protection against CLP-induced sepsis via inhibition of NFKB phosphorylation.

\section{DECLARATIONS}

\section{Acknowledgement}

The authors are thankful to Department of Critical Care Medicine, Xiangya Hospital Central South University, Changsha, Hunan, China for support.

\section{Conflict of interest}

No conflict of interest is associated with this work.

\section{Contribution of authors}

Zhiwen Zhou, Xiang Ren, Aiping $\mathrm{Li}$ and Wensheng Zhou performed the experimental work. Zhiwen Zhou carried out the literature study and compiled the data. Li Huang designed the study and wrote the manuscript. All the authors wrote the paper before communication.

\section{Open Access}

This is an Open Access article that uses a funding model which does not charge readers or their institutions for access and distributed under the terms of the Creative Commons Attribution License (http://creativecommons.org/licenses/by/ 4.0) and the Budapest Open Access Initiative (http://www.budapestopenaccessinitiative.org/rea d), which permit unrestricted use, distribution, and reproduction in any medium, provided the original work is properly credited.

\section{REFERENCES}

1. Hotchkiss RS, Karl IE. The pathophysiology and treatment of sepsis. N Engl J Med 2003; 348: 138150.

2. Martin GS, Mannino DM, Eaton S, Moss M. The epidemiology of sepsis in the United States from 1979 through 2000. N Engl J Med 2003; 348: 15461554.

3. Angus DC, Linde Zwirble WT, Lidicker J, Clermont G, Carcillo J, Pinsky MR. Epidemiology of severe sepsis in the United States: Analysis of incidence, outcome, and associated costs of care. Crit Care Med 2001; 29: 1303 1310.

4. Blackwell TS, Christman JW. Sepsis and cytokines: Current status. Br J Anaesth 1996; 77: 110117.

5. World Health Organization. Principles of laboratory animal care. WHO Chron 1985; 39: 51-56.

6. Pinsky MR, Vincent JL, Deviere J, Alegre M, Kahn RJ, Dupont E. Serum cytokine levels in human septic shock. Relation to multiple system organ failure and mortality. Chest 1993; 103: 565575.

7. Srivastava, Anupam, Pandeya SN. Indole: A versatile nucleus in pharmaceutical field. Int $J$ Curr Pharma Rev and Res 2011; 1(3): 1-17.

8. Dalpozzo R, Bartoli G. Bartoli Indole Synthesis. Current Organic Chemistry 2005; 9: 163-178.

9. Dubey PK, Kumar VT. Synthesis of indole derivatives as potential COX-2 inhibitors. Ind J Chem 2006; 45B: 21282132.

10. Chandra T, Garg N, Kumar A. Synthesis and antiinflammatory activity of indole derivatives. Int $\mathrm{J}$ Chem Tech Res 2010; 2(2): 762-773.

Trop J Pharm Res, June 2019; 18(6): 1165 
11. Thirumurugan P, Mahalaxmi S, Perumal PT. Synthesis and anti-inflammatory activity of indole derivatives. $J$ Chem Sci 2010; 122(6): S819-832.

12. Hu H, Yang B, Li Y, Zhang S, Li Z. Blocking of the P2X7 receptor inhibits the activation of the MMP-13 and NF$K B$ pathways in the cartilage tissue of rats with osteoarthritis. Inter J Mol Med 2016; 38: 1922-1932.

13. Fry DE. Sepsis, systemic inflammatory response, and multiple organ dysfunction: The mystery continues. Am Surg 2012; 78: 1-8.

14. Yu M, Shao D, Liu J, Zhu J, Zhang Z, Xu J. Effects of ketamine on levels of cytokines, NF kappaB and TLRs in rat intestine during CLP induced sepsis. Int Immunopharmacol 2007; 7: 10761082.

15. Frutuoso MS, Hori JI, Pereira MS, Junior DS, Sônego F, Kobayashi KS, Flavell RA, Cunha FQ, Zamboni DS. The pattern recognition receptors Nod1 and Nod2 account for neutrophil recruitment to the lungs of mice infected with Legionella pneumophila. Microbes Infect 2010; 12 : 819827.

16. Hasegawa $M$, Fujimoto $Y$, Lucas $P C$, Nakano $H$, Fukase $K$, Núñez G, Inohara N. A critical role of RICK/RIP2 polyubiquitination in Nod induced NF kappaB activation. EMBO J 2008; 27: 373383.

17. Magalhaes JG, Lee J, Geddes K, Rubino S, Philpott DJ, Girardin SE. Essential role of Rip2 in the modulation of innate and adaptive immunity triggered by Nod1 and Nod2 ligands. Eur J Immunol 2011; 41: 14451455.
18. Hu C, Sun L, Hu Y, Lu D, Wang H, Tang S. Functional characterization of the NF kappaB binding site in the human NOD2 promoter. Cell Mol Immunol 2010; 7: 288 295.

19. Brenmoehl J, Herfarth H, Glück T, Audebert F, Barlage S, Schmitz G, Froehlich D, Schreiber S, Hampe J, Schölmerich J. Genetic variants in the NOD2/CARD15 gene are associated with early mortality in sepsis patients. Intensive Care Med 2007; 33: 15411548.

20. Hayden MS, Ghosh S. Shared principles in NF kappaB signaling. Cell 2008; 132: 344362.

21. Arnalich F, Garcia Palomero E, López J, Jiménez M, Madero R, Renart J, Vázquez JJ, Montiel C. Predictive value of nuclear factor kappaB activity and plasma cytokine levels in patients with sepsis. Infect Immun 2000; 68: 19421945.

22. Feng X, Ren B, Xie W, Huang Z, Liu J, Guan R, Duan M, $X u \mathrm{~J}$. Influence of hydroxyethyl starch 130/0.4 in pulmonary neutrophil recruitment and acute lung injury during polymicrobial sepsis in rats. Acta Anaesthesiol Scand 2006; 50: 10811088.

23. Feng $X$, Yan W, Liu X, Duan M, Zhang X, Xu J. Effects of hydroxyethyl starch $130 / 0.4$ on pulmonary capillary leakage and cytokines production and NF kappaB activation in CLP induced sepsis in rats. J Surg Res 2006; 135: 129136. 